организуется наблюдение за изменением слова путь. Помимо формирования исследовательских навыков, подобные упражнения значительно расширяют словарный запас младшего школьника, обеспечивая правильное употребление словоформ.

Блок контрольных заданий позволяет определить уровень технического освоение алгоритма проверки падежных окончаний, а также в рамках сочинения-рассуждения продемонстрировать уровень осознанности темы.

Структурирование учебного материала в форме силлабуса соответствует требованиям информатизации учебного процесса и очень легко интерпретируется в любую цифровую «оболочку», т.е. силлабус может быть легко запрограммирован и представлен в виде модульного тренажера по теме. Это особенно актуально при организации дистанционного обучения младшего школьника на случай его продолжительного отсутствия в школе. Силлабус открывает широкие возможности и для обучающихся, заинтересованных в дополнительном, углубленном изучении предмета.

Традиционно-обязательным атрибутом силлабуса является оценочный инструментарий, в настоящее время ведется поиск наиболее результативных форм контроля, позволяющих осуществить самостоятельное оценивание уровня имеющихся знаний младшим школьником.

Внедрение силлабуса в образовательный процесс начальной школы - это

необходимый инструмент формирования умений и навыков в овладении, изучении, усвоении и систематизации приобретенных знаний, обеспечивающий высокий уровень успеваемости в процессе обучения.

$$
* * *
$$

1. Репкин В. В., Восторгова Е. В., Некрасова Т. В. Русский язык. 3 класс. Учебник. В 2-х частях., издательство "Вита-Пресс", 2005 год.

\title{
Нахматулина А.P. \\ Ситуация успеха как средство формирования преемственных компетенций будущих техников-технологов
}

«Казанский наџиональный исследовательский технологический университет» Казанский технологический колледж (Россия, Казань)

doi: $10.18411 / l j-31-01-2018-14$

idsp: 000001:lj-31-01-2018-14

\section{Аннотация}

Использование в образовательном процессе приемов создания ситуации успеха для развития личностно-мотивационной составляющей преемственных компетенций является одним из важных условий формирования учебной (познавательной) мотивации, которая создает основу для успешности освоения компетенций на этапе освоения профессии.

Ключевые слова: преемственные компетенции, ситуация успеха.

В связи с развитием новых образовательных комплексов и учреждений, появлением альтернативных учебных заведений, реализацией вариативных образовательных программ и современных педагогических технологий [4], особенно актуальным становится вопрос преемственности для решения проблемы обеспечения непрерывности профессионального образования. 
Основными признаками преемственности являются: наличие связей между различными этапами или ступенями развития объекта исследования, сохранение элементов целого или отдельных его характеристик при переходе к новому состоянию. В настоящем исследовании в качестве такого объекта выступают компетенции. Основным компонентом компетенции являются умения (операционно-деятельностный компонент). Знания (знаниевый компонент компетенции) выступают в качестве ориентировочной основы деятельности. Мотивационно-личностный компонент компетенции позволяет наилучшим образом успешно осваивать знания и выполнять умения, т.е. определяет успешность выполнения той или иной деятельности.

Рассмотрение компонентов, входящих в компетенции, показало наличие взаимосвязи между ними и наличие связей между различными этапами их развития. Таким образом, исходя из содержания понятий преемственности и компетенций нами дано определение понятия «преемственные компетенции», под которыми понимается группа компетенций, последовательно формируемых и развиваемых на различных уровнях системы непрерывного образования, связанных между собой направленностью на осуществление одноименного вида деятельности, сохраняющих отдельные компоненты при переходе к следующей образовательной ступени [3].

Отбор компетенций в группу преемственных возможен на основе сравнительного анализа квалификационных характеристик, профессиограмм, научных моделей профессиональной деятельности, образовательных стандартов профессионального образования, содержащих требования, предъявляемые к специалисту с различным уровнем профессионального образования.

Использование в образовательном процессе приемов создания ситуации успеха для развития личностно-мотивационной составляющей преемственных компетенций является одним из важных условий формирования учебной (познавательной) мотивации, которая создает основу для успешности освоения компетенций на этапе освоения профессии.

В педагогике ситуация успеха - это целенаправленный, специально организованный комплекс условий, создающих возможность достижения значимых результатов в деятельности как отдельно взятой личности, так и группы обучающихся в целом [1].

Переживание ситуации успеха обучающимся повышает учебную мотивацию и развивает познавательные интересы; позволяет обучающемуся почувствовать удовлетворение от учебной деятельности; стимулирует к высокой результативности труда; корректирует личностные особенности такие, как тревожность, неуверенность, самооценку; развивает инициативность, креативность, активность; поддерживает в группе благоприятный психологический климат.

Организация ситуации успеха может быть реализована как на уровне всего образовательного учреждения через привлечение студентов к участию в олимпиадах, викторинах и т.п.; популяризацию и поощрение личных достижений обучающихся, так и на уровне конкретной дисциплины.

Важным на уровне дисциплины является снятие страха, что помогает обучающемуся преодолеть неуверенность в собственных силах, робость, боязнь самого дела и оценки окружающих. Во многом обеспечение данного условия определяется компетентностью педагога, его способностью использовать вербальные (речевые) и невербальные (мимико-пластические) средства.

Достижение успеха обучающимся в учебной деятельности затрудняется недостатком знаний и умений, психологическими и физиологическими особенностями развития, слабой саморегуляцией и другими, что требует разработки индивидуальных 
траекторий освоения содержания дисциплины и использования метода дифференцированного обучения.

Основу дифференцированного обучения составляет организация разноуровневых групп обучающихся в соответствии с дидактическими целями. Для каждой группы преподавателем отбирается определенное содержание обучения, соответствующее уровню подготовленности и потребностям обучающихся. Разбиение на разноуровневые группы может быть как на этапе изучения нового материала, закрепления и применения усвоенных знаний, так и на этапе контроля и проверки знаний [2]. Деление группы на подгруппы помогает организовать взаимопроверку выполненных заданий.

В рамках дифференцированного обучения обучающимся предоставляется право выбора содержания, методов и форм обучения. Выбор осуществляется из предлагаемых педагогом заданий, имеющих одно и то же содержание, но предоставляемых в разной форме, разного объема, разной сложности, то есть заданий, требующих от обучающихся включения разных типов мышления. Обучающимся сообщается о наличии заданий разной степени сложности и предлагается каждому самостоятельно выбрать задание, которое вызывает интерес, или с которым он справится наилучшим образом. Это требует подготовки обучающихся к такому выбору, у него должны быть сформированы умения работать самостоятельно, необходима постоянная воспитательная работа. Поэтому для того, чтобы выработать способности у обучающихся не теряться в ситуации выбора, осознанно выбирать работу по силам, умение объективно оценивать свои возможности, необходимо предлагать задания на выбор систематически.

Таким образом, использование в образовательном процессе приемов создания ситуации успеха для развития личностно-мотивационной составляющей преемственных компетенций является одним из важных условий формирования учебной (познавательной) мотивации. Создается основа для успешного освоения компетенций на этапе освоения профессии.

$$
* * *
$$

1. Азаров, Ю.П. Радость учить и учиться / Ю.П.Азаров. - М.: Политиздат, 1989. - 336с.

2. Асадуллин, Р.М. Принципы построения индивидуальных образовательных траекторий на основе самоорганизации студентов / Р.М.Асадуллин, Л.И.Васильев // Педагогический журнал Башкортостана. - 2012. - № 5. - C.58-66.

3. Нахматулина, А.Р. Преемственные компетенции и условия их формирования в процессе химической подготовки / А.Р.Нахматулина // Казанская наука. - 2013. - №.2 - С.166-168.

4. Шагеева, Ф.Т. Образовательные технологии подготовки современного инженера-технолога / Ф.Т.Шагеева, В.Г.Иванов // Высшее образование в России. - 2014. - №.1 - С.129-133.

\section{Феуерман В.В., Онищенко Д.В. \\ Техническая подготовка в игровых вида спорта и физическая подготовленность как фактор её определяющая}

Крымский федеральный университет имени В.И. Вернадского doi: $10.18411 / l j-31-01-2018-15$

(Россия, Симферополь)

idsp: 000001:lj-31-01-2018-15

\section{Аннотация}

В статье анализируются процессформирования координационных способностей обучающихся 11-12 лет, которые выступают основным критерием эффективностифизической подготовленности на этапе начальной подготовки в волейболе, принципы построение учебно-тренировочного процесса влияющие на физические качества обучающихся. 